УДК 330.1:338

DOI: https://doi.org/10.37320/2415-3583/10.13

Ткачук Г.О.

кандидат економічних наук, доцент, Одеська начіональна академія харчових технологій ORCID: http://orcid.org/0000-0001-6937-6223

\title{
ЕКОНОМІЧНА БЕЗПЕКА ПІДПРИЕМСТВА: ВЕКТОР АКТУАЛЬНИХ НАУКОВИХ ДОСЛІДЖЕНЬ
}

Статтю присвячено огляду сучасних наукових досліджень у галузі економічної безпеки підприємства. Визначено структуру наукових досліджень економічної безпеки та надано стислу характеристику кожного ї̈ елементу. Означено базову структуру фундаментальних авторських доробок. Представлено результати проведеного оглядово-вибіркового аналізу наукових уподобань за 2009-2019 рр. та виділено вектори сучасних наукових доробок шодо економічної безпеки підприємства. За результатами проведеного аналізу та систематизаиї отриманих результатів зроблено висновки щодо актуальності досліджень у напрямі вдосконалення системи економічної безпеки підприємства. Наголошено на актуальності поглибленого вивчення проблематики та особливостей системи економічної безпеки для підприємств харчової промисловості.

Ключові слова: підприємство, економічна безпека підприємства, наукове дослідження, вектор наукових досліджень, напрями наукових досліджень.

Постановка проблеми. Дослідження проблематики організації та функціонування системи економічної безпеки $є$ різновекторним, що значно розширює пізнання процесів забезпечення захисту економічної системи підприємства від загроз та небезпек ендогенного та екзогенного середовища, які негативно впливають на фінансовий стан підприємства, його конкурентоспроможність та забезпечення умов стабільного розвитку. Вибір того чи іншого вектору наукових уподобань визначає структуру та зміст теоретичного базису самого дослідження. Вибір наукового напряму формується залежно від ступеню опанування різних сфер економічної безпеки та актуальності акцентованих проблемних аспектів вибраного вектору дослідження. За таких обставин важливим $€$ попереднє вивчення кола наукових інтересів у галузі забезпечення безпечної діяльності країни, окремих її регіонів та підприємств.

Аналіз останніх досліджень і публікацій. Вивченню актуальних питань організації, функціонування, управління, забезпечення та інших боків економічної безпеки підприємства присвячено багато фундаментальних праць у вигляді дисертацій, монографій, наукових посібників та поодиноких наукових та науково-популярних статей і доповідей іноземних та вітчизняних авторів. Проблематика створення надійної системи економічної безпеки на всіх рівнях економіки цікавить таких науковців, як Л.І. Донець, В.М. Геєць, О.В. Ілляшенко, Г.В. Козаченко, М.I. Копитко, Н.Л. Корженівська, О.М. Ляшенко, Л.Я. Малюта, Є.I. Овчаренко та ін.

Уважаємо доречним провести аналітичний огляд наукових джерел та узагальнення наукових тенденцій щодо вдосконалення системи економічної безпеки підприємства. Актуальність такого роду дослідження підтверджується зростанням ролі системи захисту сучасного бізнесу від загроз економічній системі підприємства за умов зовнішніх та внутрішніх трансформаційних зрушень.

Мета статті полягає в узагальненні інформації щодо напрямів наукових доробок у галузі економічної безпеки підприємства та визначенні ймовірних напрямів подальших наукових досліджень.

Виклад основного матеріалу. Проведений нами вибірковий аналітичний огляд науковопопулярних джерел показав, що дослідження проблематики економічної безпеки проводиться на декількох рівнях (рис. 1):

1. На міжнародному (глобальному) рівні вивчаються суспільно значимі питання забезпечення економічної безпеки світової спільноти у цілому в умовах масштабних глобалізаційних процесів, міжнародної співпраці та світової економіки. Являє собою «комплекс міжнародних умов існування домовленостей та інституційних структур, за якого кожній державі - члену світової спільноти забезпечується можливість вільно вибирати і здійснювати свою стратегію соціального та економічного розвитку, не піддаючись зовнішньому і політичному тиску, розраховуючи на невтручання, розуміння і взаємоприйнятну та взаємовигідну співпрацю з боку решти держав» [1]. Поняття «міжнародна економічна безпека» щільно пов'язане з категорією «глобальна безпека», яка розглядається як «такі умови співіснування інституціональних структур, за яких кожен член світової спільноти має можливість вільно вибирати і здійснювати свою стратегію розвитку відповідно до принципів глобалізації» [2, с. 58]. Вивченню проблематики глобальної та міжнародної економічної безпеки присвячено роботи сучасних вітчизняних дослідників 


\section{РІВНІ НАУКОВОГО ДОСЛІДЖЕННЯ ЕКОНОМІЧНОЇ БЕЗПЕКИ}

\begin{tabular}{|c|}
\hline 1.Глобальна \\
(міжнародна) \\
економічна безпека \\
(В.М. Кулагин, \\
О.В. Коломієць, \\
О.Б. Чернега, \\
I.А. Іваненко та ін.) \\
\hline Основний вектор \\
дослідження - за \\
складовими \\
елементами ЕБ \\
\hline
\end{tabular}

\begin{tabular}{|c|}
\hline 2.Економічна безпека \\
України \\
(О.М. Бандурка, \\
3.С. Варналій, \\
В.О. Гончарова, \\
Я.А. Жаліло, В.І. Мунтян, \\
В.Т. Шлемко та ін.) \\
\hline Основний вектор \\
дослідження - за \\
складовими \\
елементами ЕБ \\
\hline
\end{tabular}

\begin{tabular}{|c|}
\hline 3.Економічна безпека \\
регіону \\
(3.В. Герасимчук, \\
О.М. Головченко, \\
В.С. Пономаренко, \\
А.I. Сухоруков та ін.) \\
\hline Основний вектор \\
дослідження - за \\
складовими \\
елементами ЕБ \\
\hline
\end{tabular}

\begin{tabular}{|c|}
\hline 4.Економічна безпека \\
галузі \\
(В.Г. Алькема, О.С. Денисов, \\
М.С. Кіржецька, \\
Ю.І. Кіржецький та ін.) \\
\\
\hline Основний вектор \\
дослідження - за \\
складовими елементами ЕБ \\
\hline
\end{tabular}

\begin{tabular}{|c|}
\hline 5.Економічна безпека \\
підприємства \\
(Н.В. Білошкурська, \\
О.В. Ілляшенко, \\
М.І. Копитко, \\
Н.Л. Корженівська, \\
О.М. Ляшенко, \\
Л.Я. Малюта, \\
С.І. Овчаренко та ін.) \\
\hline Основний вектор \\
дослідження - за \\
складовими елементами ЕБ \\
\hline
\end{tabular}

\section{БАЗОВА СТРУКТУРА НАУКОВИХ ДОСЛІДЖЕНЬ ЗА ВИБРАНИМ ВЕКТОРОМ}

\begin{tabular}{|c|}
\hline $\begin{array}{c}\text { Теоретичний } \\
\text { базис ЕБ }\end{array}$ \\
\hline
\end{tabular}

\begin{tabular}{|l|}
\hline Ризики, загрози \\
та небезпеки ЕБ \\
\hline
\end{tabular}

Забезпечення
системи ЕБ

\begin{tabular}{|c|}
\hline Оцінка стану та \\
рівня ЕБ \\
\hline
\end{tabular}

Рис. 1. Структура наукових досліджень економічної безпеки

Джерело: авторська розробка

В.М. Кулагина, О.В. Коломієця, О.Б. Чернеги, I.А. Іваненко та ін.

2. Національна економічна безпека України широко розповсюджений рівень дослідження, який охоплює проблемні питання забезпечення безпеки країни у цілому від зовнішніх загроз, які виникають у зв' язку з активним курсом України на євроінтеграцію, процесами глобалізації, внутрішніми небезпеками трансформації пострадянського середовища. Під економічною безпекою держави розуміють «сукупність умов, що забезпечують незалежність національної економіки, іiі стабільність і стійкість, здатність до постійного відновлення і самовдосконалення, здатність економіки забезпечувати ефективне задоволення ендогенних та екзогенних суспільних потреб» [3]. Вивченню особливостей функціонування системи економічної безпеки на рівні країни присвячено роботи
О.М. Бандурки, 3.С. Варналія, В.О. Гончарової, Я.А. Жаліла, В.І. Мунтян, В.Т. Шлемко та ін.

3. Економічна безпека на регіональному рівні висвітлюється у наукових доробках 3.В. Герасимчук, О.М. Головченко, В.С. Пономаренко, A.I. Сухорукова як проблемні аспекти економічної безпеки конкретного регіону під впливом трансформаційних процесів зовнішньоекономічної та регіональної політики держави, інтеграційних та реструктаційних зрушень. Економічна безпека регіону - сукупність взаємовпливу економічних інтересів та загроз, що забезпечують його стійке функціонування, конкурентоспроможність і самодостатність, а також сприяють підвищенню рівня й якості життя населення в контексті забезпечення національної економічної безпеки [4].

4. Економічна безпека галузі вивчає особливості організації та функціонування системи 
економічної безпеки конкретної галузі господарювання (промисловості, транспорту, торгівлі тощо) під впливом трансформації (видозміни) галузевої (промислової) політики країни та регіону. На жаль, не так багато робіт присвячено комплексному дослідженню специфічних аспектів конкретних галузей виробництва, тому праці таких авторів, як В.Г. Алькема [5], О.С. Денисов [6], М.С. Кіржецька [7] та ін., уважаємо актуальними на сучасному етапі економічного розвитку. На нашу думку, особливої уваги заслуговує забезпечення ефективної та безпечної діяльності галузі харчової промисловості, яке відіграє важливу роль у забезпеченні продовольчої безпеки конкретного регіону, країни взагалі та в глобальному масштабі.

5. Економічна безпека підприємства вивчає систему забезпечення захищеності підприємства від зовнішніх та внутрішніх загроз під впливом промислової політики, корпоративної політики, чинників впливу трансформаційних зрушень політики безпеки бізнесу на макро- і мезорівні. Фундаментальні дослідження за цим напрямом представлено роботами Н.В. Білошкурської [8], О.В. Ілляшенко [9], М.I. Копитко [10], Н.Л. Корженівської [11], О.М. Ляшенко [12], Л.Я. Малюти [13], Є.І. Овчаренко [14] та багатьох інших.

На рис. 1 представлено структуру наукового дослідження економічної безпеки, у якій показано, що основним змістом дослідження кожного iз зазначених рівнів $є$ дослідження за відповідними структурними компонентами, які найчастіше подібні до функціональних складників економічної безпеки певного рівня.

За результатами аналітичного огляду структури фундаментальних наукових праць 3 економічної безпеки (дисертацій, монографій, навчальних посібників) найчастіше структура певного авторського доробка представлена такими базовими елементами, як:

- теоретичний базис економічної безпеки;

- ризики, загрози та небезпеки економічній безпеці;

- забезпечення системи економічної безпеки;

- оцінка стану та рівня безпечності (небезпеки).

Уважаємо, що така структура дослідження $є$ раціональною, адже відповідає основним завданням системи економічної безпеки будь-якого рівня:

- постійно знаходитися у «бойовій» готовності: прогнозувати ймовірність ризиків і загроз, планувати вірогідні засоби захисту та проводити профілактичні заходи;

- своєчасно виявити та ідентифікувати реальні загрози та небезпеки;

- оперативно оцінити рівень небезпеки та стан системи економічної безпеки;

- оперативно запровадити відповідні засоби захисту.
Сучасне промислове підприємство знаходиться під тиском як заздалегідь спланованих, так і непередбачуваних подій та процесів, які мають як позитивний, так і негативний вплив на економічну систему підприємства. У таких умовах зростає потреба у дієвому механізмі захисту від негативних наслідків таких подій. При цьому економічна система промислового підприємства являє собою зменшену версію економічної системи країни у цілому на кшталт кожної окремої сім’ї, яка є моделлю суспільства.

Вивчаючи теоретичні засади системи економічної безпеки на підприємстві, можна змоделювати дієву систему забезпечення захисту від загроз та небезпек, яку частково можна запровадити для більш складних економічних систем.

Вибірковий аналіз даних вебсайтів вищих навчальних закладів України (ВНЗ «Університет економіки та права «КРОК», ДВНЗ «Прикарпатський національний університет імені В. Стефаника», Державний університет інфраструктури та технологій, Одеська національна академія харчових технологій, Подільський державний аграрно-технічний університет, Харківський національний університет міського господарства імені О.М. Бекетова, Херсонський національний технічний університет, Хмельницький національний університет) та інших Інтернет-ресурсів дав змогу зробити вибірку напрямів наукових інтересів у галузі економічної безпеки підприємства та означити вектори досліджень (табл. 1).

Таким чином, означено шість векторів сучасних наукових доробок щодо економічної безпеки підприємства:

1) дослідження теоретичних аспектів системи економічної безпеки, систем іiі забезпечення та управління на рівні підприємства;

2) дослідження економічної безпеки підприємства за окремими функціональними складниками;

3) дослідження економічної безпеки підприємств різних галузей;

4) дослідження економічної безпеки за окремими сферами діяльності;

5) дослідження економічної безпеки за окремими видами підприємств;

6) дослідження економічної безпеки за різними умовами економічного середовища функціонування підприємства, а саме:

- за умов глобалізації світової економіки;

- в умовах інтеграції України у світову економіку;

- за умов нестабільного економічного середовища;

- у процесі розвитку регіональної інтеграції;

- за умов трансформаційної економіки.

Актуальність дослідження економічної безпеки підприємства за умов трансформаційних перетворень зумовлена такими дестабілізуючими чинниками: 
Таблиця 1

Вектори сучасних наукових доробок щодо економічної безпеки підприємства (2009-2019 рр.)

\begin{tabular}{|c|c|c|}
\hline \multicolumn{3}{|c|}{ Вектори наукових досліджень економічної безпеки підприсмства } \\
\hline \multicolumn{3}{|c|}{ 1.Дослідження теоретичних аспектів системи економічної безпеки підприємства } \\
\hline $\begin{array}{c}\text { - управління економічною безпекою } \\
\text { (О.М. Ляшенко, Ю.О. Нестеров) }\end{array}$ & $\begin{array}{c}\text { - концепція економічної безпеки } \\
\text { (О.В. Мороз, Н.П. Карачина, } \\
\text { А.А. Шиян) } \\
\end{array}$ & $\begin{array}{c}\text { - цілі в системі економічної безпеки } \\
\text { (Є.І. Овчаренко) }\end{array}$ \\
\hline $\begin{array}{c}\text { - механізми економічної безпеки } \\
\text { (О.В. Ілляшенко) }\end{array}$ & \multirow{2}{*}{$\begin{array}{c}\text { - забезпечення: обліково-аналітичне } \\
\text { (Л.В. Гнилицька), організаційне } \\
\text { (Л.Я. Малюта) }\end{array}$} & \multirow{2}{*}{$\begin{array}{c}\text { - діагностика та оцінка економічної } \\
\text { безпеки (Е.В. Камишникова, } \\
\text { Г.М. Пазєєва, І.В. Шутяк) }\end{array}$} \\
\hline $\begin{array}{c}\text {-трансформації системи } \\
\text { (Є.А. Івченко) }\end{array}$ & & \\
\hline \multicolumn{3}{|c|}{ 2.Дослідження економічної безпеки за окремими функиіональними складниками } \\
\hline \multirow{2}{*}{$\begin{array}{c}\text { - фінансово-економічна безпека } \\
\text { (Л.В. Гнилицька, О.А. Кириченко, } \\
\text { Ю.Г. Кім, О.В. Малик, } \\
\text { В.В. Немченко, П.Я. Пригунов) }\end{array}$} & \multirow{2}{*}{$\begin{array}{c}\text { - інформаційна безпека (С.В. Кавун, } \\
\text { А.А. Пилипенко, Д.О. Репко, } \\
\text { А.О. Чередниченко, С.В. Цюцюпа) }\end{array}$} & - кадрова безпека (Ю.А. \\
\hline & & $\begin{array}{l}\text { - корпоративна безпека } \\
\text { (О.Я. Кравчук, Н.О. Чех) }\end{array}$ \\
\hline - технологічна безпека (Л.І. Крачок) & $\begin{aligned} \text { - соціально-ел } \\
\text { (В.Л. Е }\end{aligned}$ & $\begin{array}{r}\text { - енергетична (O } \\
\text { Я.О. Кол } \\
\end{array}$ \\
\hline \multicolumn{3}{|c|}{ 3.Дослідження економічної безпеки підприємств різних галузей } \\
\hline $\begin{array}{c}\text { - оборонно-промисловий комплекс } \\
\text { (Н.Е. Аванесова) }\end{array}$ & - підприємства нафтс & $\begin{array}{c}\text { - гірничо-добувні (Д.П. Дубиц } \\
\text { О.М. Молодецька) }\end{array}$ \\
\hline $\begin{array}{c}\text { - будівельні (О.Л. Коробчинс } \\
\text { Т.В. Азарова) }\end{array}$ & \multirow{2}{*}{$\begin{array}{c}\text { - підприємства транспортного } \\
\text { машинобудування (М.I. Копитко, } \\
\text { М.С. Хаванова) }\end{array}$} & \multirow{2}{*}{$\begin{array}{c}\text { - транспортно-експедиційні } \\
\text { підприємства (С.А. Лебедко, } \\
\text { Г.М. Пазєєва) }\end{array}$} \\
\hline $\begin{array}{r}\text { - підприємства зв } \\
\text { (О.О. Сосновсь }\end{array}$ & & \\
\hline \multirow{2}{*}{$\begin{array}{c}\text { - підприємства харчової } \\
\text { промисловості (М.С. Кіржецька, } \\
\text { Ю.І. Кіржецький, К.С. Фень, } \\
\text { О.А. Хоменко) }\end{array}$} & \multirow{2}{*}{$\begin{array}{c}\text { - агропромислові (Н.С. } \\
\text { Іванова, Н.Л. Корженівська, } \\
\text { М.М. Максимюк, Д.С. Степанов, } \\
\text { Н.М. Голович, Н.В. Білошкурська) }\end{array}$} & $\begin{array}{r}\text { - підприємств } \\
\text { (В.М. Ч }\end{array}$ \\
\hline & & $\begin{array}{r}\text { - логісти } \\
\text { (В.Г. }\end{array}$ \\
\hline $\begin{array}{l}\text { - торгівля (О.Р. Бойкевич, } \\
\text { С.М. Яременко) }\end{array}$ & $\begin{array}{c}\text { - підприємства ресторанного } \\
\text { бізнесу (О.О. Борисова) }\end{array}$ & $\begin{array}{r}\text { - підприємства с } \\
\text { (С.I. Д }\end{array}$ \\
\hline \multicolumn{3}{|c|}{ 4.Дослідження економічної безпеки за окремими сферами діяльності } \\
\hline $\begin{array}{c}\text { - інвестиційна діяльність } \\
\text { (О.Б. Злотенко) }\end{array}$ & $\begin{array}{c}\text { - зовнішньоекономічна діяльність } \\
\text { (Н.І. Гавловська, Л.А. Кримчак) }\end{array}$ & - емісійна діяльність (І.П. Шульга) \\
\hline \multicolumn{3}{|c|}{ 5.Дослідження економічної безпеки за окремими видами підприємств } \\
\hline $\begin{array}{r}\text { - підприємств малого бі } \\
\text { (Г.О. Гончаров, О.А. Соро }\end{array}$ & \multirow{2}{*}{$\begin{array}{l}\text { - великі підприємства } \\
\text { (В.Л. Безбожний) }\end{array}$} & \multirow{2}{*}{$\begin{array}{l}\text { - інноваційні проєктно-орієнтовані } \\
\text { підприємства (І.В. Россошанська) }\end{array}$} \\
\hline $\begin{array}{c}\text { - акціонерні товариства } \\
\text { (В.І. Франчук, О.О. Солодовнік) }\end{array}$ & & \\
\hline \multicolumn{3}{|c|}{ 6.Дослідження за різними умовами функиііонування } \\
\hline $\begin{array}{c}\text { - за умов нестабільного } \\
\text { економічного середовища } \\
\text { (Ю.О. Нестеров) } \\
\end{array}$ & $\begin{array}{c}\text { - у процесі розвитку регіональної } \\
\text { інтеграції (С.М. Цевух) }\end{array}$ & \multirow{2}{*}{$\begin{array}{l}\text { - за умов трансформаційної } \\
\text { економіки (B.I. Франчук) }\end{array}$} \\
\hline $\begin{array}{c}\text { - за умов глобалізації світової } \\
\text { економіки (О.С. Денисов) }\end{array}$ & $\begin{array}{c}\text { - в умовах інтеграції України } \\
\text { у світову економіку (В.В. Немченко) }\end{array}$ & \\
\hline
\end{tabular}

Джерело: авторська розробка

1) Відсутність в Україні вітчизняної або адаптованої до національних умов, моделі трансформації економіки на ринкових засадах [Радченко О.І., Шавалюк О.І. Особливості становлення трансформаційних процесів економіки України. Ринкова економіка: сучасна теорія і практика управління. 2014. Т. 1. Вип. 2/2. С. 106-109], що провокує невпорядкованість та безсистемність змін в економічній та фінансово-кредитній системах і викликає загрози економічній системі та фінансовому стану підприємства.
2) Процеси глобалізації та євроінтеграції прискорюють інтеграцію економіки України та ії підприємств до світової спільноти, активізується зовнішньоекономічна діяльність, зростає тиск із боку міжнародних корпорацій та вплив світових організацій (наприклад, Міжнародного фінансового банку). Налагодження нових бізнес-стосунків, освоєння нових правил бізнес-гри $є$ каталізатором збільшення ймовірної ризикованості бізнес-проєктів.

3) Зростання конкуренції на ринку продовольчих товарів та виклики продовольчої безпеки 
вимагають якісних змін технології вирощування та переробки сільгоспсировини, виробництва продукції, перетворення системи управління якістю, управління запасами тощо. Запровадження технологічних інновацій $є$ своєрідним викликом для системи економічної безпеки.

На нашу думку, важливим вектором наукових доробок має бути харчова промисловість. Таку впевненість забезпечують такі фактори:

1) необхідність виконання вимог продовольчої безпеки регіону, країни;

2) урахування географічного аспекту (Україна - агропромислова країна з великим сільськогосподарським потенціалом);

3) забезпечення національної економічної безпеки. Обов'язковою умовою економічного зростання держави та забезпечення іiі економічної безпеки $\epsilon$ збільшення частки експорту саме готової продукції, а не тільки сільськогосподарської сировини.

Друге десятиліття XXI ст. принесло із собою низку фундаментальних досліджень економічної безпеки підприємства, зорієнтованих на створення або вдосконалення системи економічної безпеки для підприємств харчової промисловості за окремими ii галузями $[7 ; 15 ; 16]$, але цього недостатньо i дослідження в даному напрямі необхідно продовжувати.

Важливим напрямом дослідження залишається вивчення особливостей формування та функціо- нування системи економічної безпеки на рівні підприємства, що пояснюється такими чинниками:

1) недосконалістю законодавчої бази щодо економічної безпеки підприємства та відсутністю відповідного нормативно-методичного забезпечення;

2) наявністю реальних загроз економічній системі підприємства у зв'язку з проведенням реформування економіки;

3) необхідністю адаптації існуючої системи ідентифікації, оцінки та захисту від загроз до умов трансформаційних перетворень, які зумовлені ринковими чинниками, процесами євроінтеграції та глобалізації.

Висновки. За результатами проведених досліджень можна зробити такі висновки:

- дослідження економічної безпеки підприємства носить багатовекторний характер;

- зростаюча потреба у вирішенні проблем забезпечення людства продовольством спонукає звернути більше уваги на розвиток системи економічної безпеки у харчовій галузі виробництва;

- глобалізаційні та євроінтеграційні зміни розширюють коло наукових інтересів щодо безпеки трансформаційних перетворень внутрішнього та зовнішнього характеру.

Таким чином, економічна безпека підприємства залишається цікавим об'єктом для проведення наукових досліджень.

\section{Список використаних джерел:}

1. Економічна безпека в умовах глобалізації світової економіки : колективна монографія : у 2-х т. Дніпро : ФОП Дробязко С.I., 2014. T. 1. 466 с.

2. Сороківська О.А. Інноваційні напрями підвищення економічної безпеки підприємств малого бізнесу в умовах конфліктних ситуацій : дис. ... д.е.н. : 08.00.04 ; Тернопільський національний технічний університет імені Івана Пулюя. Тернопіль, 2016. 488 с.

3. Попадинець Н.М. Основні чинника забезпечення економічної безпеки України. Сочіально-економічні проблеми сучасного періоду Украӥни. 2016. Вип. 2(118). С. 20-23.

4. Заблодська I.В., Куляк А.І., Госкова С.А. Теоретичні аспекти та нормативно-правове забезпечення збалансованого розвитку регіону. Економіка та держава. 2013. № 2. С. 28-30.

5. Алькема В.Г. Система економічної безпеки логістичних утворень : монографія. Київ, 2011. 376 с.

6. Денисов О.С. Забезпечення економічної безпеки галузі в умовах глобалізації : монографія. Київ : ДКС центр, 2019. $420 \mathrm{c}$.

7. Кіржецька М.С., Кіржецький Ю.І. Економічна безпека підсистем харчової промисловості України: проблеми та пріоритети зміцнення : монографія. Львів : Ліга-Прес, 2018. 214 с.

8. Лисенко Н.О., Білошкурська Н.В. Економіко-організаційний механізм формування економічної безпеки агропромислових підприємств : монографія. Умань : Візаві, 2014. 257 с.

9. Ільяшенко О.В. Методологічні засади формування та функціонування механізмів системи економічної безпеки підприємства : дис. ... д.е.н. : 08.00.04; 21.04 .02 ; Східноукраїнський національний університет імені Володимира Даля. Сєвєродонецьк, 2016. 606 с.

10. Копитко M.I. Комплексне забезпечення економічної безпеки підприємств (на матеріалах підприємств транспортного машинобудування) : дис. ... д.е.н. : 21.04.02 ; ВНЗ «Університет економіки і права «Крок». Київ, 2015.478 с.

11. Корженівська Н.Л. Економічна безпека товаровиробників зерна в умовах ринкової глобалізації: теорія, методологія, пріоритети : дис. ... д.е.н. : спец. 09.00.04 ; Подільський державний аграрно-технічний університет. 2019.530 с.

12. Ляшенко О.М. Управління економічною безпекою підприємства : дис. ... д.е.н. : спец. 21.04.02, 08.00.04. Луганськ, 2012. 405 с.

13. Малюта Л.Я. Інституційні детермінанти організаційного забезпечення економічної безпеки підприємств в контексті їх інноваційно-технологічного розвитку : автореф. дис. ... д.е.н. : спец. 08.00.04 ; Тернопільський національний технічний університет ім. І. Пулюя. Тернопіль, 2018. 42 с.

14. Овчаренко Є.I. Методологія формування та узгодження цілей у системі економічнох безпеки підприємства : дис. ... д.е.н. : спец. 21.04.02, 08.00.04 ; Східноукраїнський національний університет імені В. Даля. Сєвєродонецьк, 2015. $631 \mathrm{c}$. 
15. Фень К.С. Формування і зміцнення економічної безпеки підприємств харчової промисловості : дис. ... к.е.н. : 08.00.04 ; Подільський державний анрарно-технічний університет. Камянець-Подільський. 2018. 273 с.

16. Хоменко О.А. Управління фінансовою безпекою молокопереробних підприємств : дис. ... к.е.н. : 08.00 .04 ; Подільський державний аграрно-технічний університет. Камянець-Подільський, 2019. 374 с.

\section{References:}

1. FOP Drobyazko S.I. (2014) Ekonomichna bezpeka v umovakh hlobalizatsiyi svitovoyi ekonomiky: kolektyvna monohrafiya $v 2$ t. [Economic security in the conditions of globalization of the world economy: a collective monograph in 2 tons] Dnepropetrovsk: Vol. 1. 466 p. (in Ukrainian)

2. Sorokivska, O.A. (2016). Innovaciyni napramy pidvyshhennya ekonomichnoi bezpeky pidpryemstv malogho biznesu $\mathrm{v}$ umovakh konfliktnykh sytuaciy [Innovative directions of increasing the economic security of small business enterprises in the context of conflict situations] (PhD Thesis). Ternopil: Ternopilskiy nacionalniy tekhnichniy universytet imeni Ivana Pulia. 488 p. (in Ukrainian)

3. Popadinets N.M. (2016) Osnovni faktory zabezpechennya ekonomichnoyi bezpeky krayin [The main factors for ensuring the economic security of the country] / Socio-economic problems of the modern period of Ukraine. Issue 2(118). P. 20-23. (in Ukrainian)

4. Zablodskaya I.V., Kulyak A.I., Goskov S.A. (2013) Teoretychni aspekty ta normatyvno-pravove zabezpechennya zbalansovanoho rozvytku rehionu [Theoretical aspects and regulatory legal support for balanced development of the region]/ Economy and state. № 2. P. 28-30. (in Ukrainian)

5. Alkema V.G. (2011) Systema ekonomichnoyi bezpeky lohistychnykh orhanizatsiy: monohrafiy [System of economic security of logistical entities: monograph] University of Economics and Law «KROK». Research Institute of Engineering. nat. security of Ukraine. K. 376 p. (in Ukrainian)

6. Denisov O.E. (2019) Zabezpechennya ekonomichnoyi bezpeky haluzi v umovakh hlobalizatsiyi: monohrafiya [Ensuring the economic security of the industry in the context of globalization: monograph] University of Economics and Law «KROK». $\mathrm{K} .:$ DCS Center. 420 p. (in Ukrainian)

7. Kirzhetska M.S., Kirzhetsky Yu.I. (2018) Ekonomichna bezpeka kharchovykh pidsystem Ukrayiny: vyklyky ta priorytety zmitsnennya: monohrafiya. [Economic security of Ukraine's food processing subsystems: challenges and priorities for strengthening: mograph] Lviv: Liga Press. 214 p. (in Ukrainian)

8. Lysenko N.O., Beloshkurskaya N.V. (2014) Ekonomichnyy ta orhanizatsiynyy mekhanizm formuvannya ekonomichnoyi bezpeky ahropromyslovykh pidpryyemstv. Monohrafiy [Economic and organizational mechanism of formation of economic security of agro-industrial enterprises. Monograph] Uman: Viscountry Center. 257 p. (in Ukrainian)

9. Ilyashenko O.V. (2016) Metodolohichni zasady formuvannya ta funktsionuvannya mekhanizmiv systemy ekonomichnoyi bezpeky pidpryyemstva [Methodological principles of formation and functioning of mechanisms of the enterprise economic security system] (PhD Thesis). Volodymyr Dahl East Ukrainian National University. Severodonetsk. 606 p. (in Ukrainian)

10. Kopitko M.I. (2015) Kompleksne zabezpechennya ekonomichnoyi bezpeky pidpryyemstv (na materialakh pidpryyemstv transportnoho mashynobuduvannya) [Complex maintenance of economic security of the enterprises (on the materials of the enterprises of transport mechanical engineering)] (PhD Thesis). Kyiv: Krok University of Economics and Law. 478 p. (in Ukrainian)

11. Korzhenivska N.L. (2019) Ekonomichna bezpeka vyrobnykiv zerna v umovakh hlobalizatsiyi rynku: teoriya, metodolohiya, priorytet [Economic security of grain producers in the market globalization: theory, methodology, priorities] (PhD Thesis). Podilsky State Agricultural and Technical University. 530 p. (in Ukrainian)

12. Lyashenko O.M. (2012) Upravlinnya ekonomichnoyu bezpekoyu pidpryyemstva. [Management of economic security of the enterprise] (PhD Thesis) Lugansk. 405 p. (in Ukrainian)

13. Malyuta L.Ya. (2018) Instytutsiyni determinanty orhanizatsiynoyi bezpeky ekonomichnoyi bezpeky pidpryyemstv u konteksti yikh innovatsiynoho ta tekhnolohichnoho rozvytku [Institutional determinants of organizational security of economic security of enterprises in the context of their innovation and technological development] (PhD Thesis). Ternopil National Technical University. I. Pulia. Ternopil: TNTU. 42 p. (in Ukrainian)

14. Ovcharenko E.I. (2015) Metodolohiya formuvannya ta uz hodzhennya tsiley u systemi ekonomichnoyi bezpeky pidpryyemstva [Methodology of formation and coordination of goals in the enterprise economic security system] (PhD Thesis). Dahl East Ukrainian National University. Severodonetsk. 631 p. (in Ukrainian)

15. Feng K.S. (2018) Formuvannya ta zmitsnennya ekonomichnoyi bezpeky pidpryyemstv kharchovoyi promyslovosti. [Formation and strengthening of economic security of food industry enterprises] (PhD Thesis). Podilsky State Anrar-Technical University. Kamianets-Podilskyi. 273 p. (in Ukrainian)

16. Khomenko O.A. (2019) Upravlinnya finansovoyu bezpekoyu molochnykh pidpryyemst [Management of financial security of dairy enterprises] (PhD Thesis). Podilsky State Agrarian and Technical University. Kamianets-Podilskyi. 374 p. (in Ukrainian) 
Tkachuk Haluna

Odessa National Academy of Food Technologies

\section{ECONOMIC SECURITY OF THE ENTERPRISE: A VECTOR OF ACTUAL RESEARCH RESEARCH}

The modern domestic enterprise operates in the conditions of development of various transformation processes, complicated by world globalization of economy and processes of European integration. The aggressiveness of the environment and the acceleration of the pace of internal transformation create the need for protection against threats and dangers. The correct choice of the vector of research of the system of the economic system of the enterprise, its provision, evaluation and remedies determines the usefulness of its results for modern business and the economy of the country as a whole. The article is devoted to the review of modern scientific researches in the field of economic security of the enterprise, which indicates the relevance of its topics. The study used the methods of review and structural analysis, the method of generalizing the results. According to the results of the structural analysis, the structure of economic security research is defined and a brief description of each element is given. The basic structure of fundamental author's achievements (dissertations, monographs, textbooks), which is most commonly used by domestic scientists, is outlined. The results of the survey and sample analysis of scientific preferences for 2009-2019 are presented in view of the available information resources. The vectors of modern scientific achievements concerning the economic security of the enterprise are highlighted: research of theoretical aspects of the system; research on individual functional components; research of economic security of enterprises of different industries; research by specific fields of activity; research on individual types of enterprises; research on different conditions of the economic environment of the enterprise. According to the results of the analysis and systematization of the obtained results, the author draws conclusions about the relevance of the research in the direction of improving the economic security of the enterprise. The author emphasizes the urgency of an in-depth study of the problems and features of the economic security system for food industry enterprises, taking into account specific sectoral features.

Key words: enterprise, economic security of enterprise, scientific research, vector of scientific researches, directions of scientific researches.

JEL classification: M21, M29. 